\title{
Tip 2 Diabetes Mellitusun Serbest Doku Nakli Başarısına Etkisi
}

\author{
Hakan ÇİNAL ${ }^{1} \otimes \square$, Ensar Zafer BARIN ${ }^{2}$ (๑) \\ ${ }^{1}$ Zonguldak Bülent Ecevit Üniversitesi, Tip Fakültesi, Plastik, Rekonstrüktif ve Estetik Cerrahi Anabilim Dall, Zonguldak, Türkiye \\ ${ }^{2}$ Atatürk Üniversitesi, Tip Fakültesi, Plastik, Rekonstrüktif ve Estetik Cerrahi Anabilim Dalı, Erzurum, Türkiye \\ Bu makaleye yapılacak atıf: Çinal H, Barın EZ. Tip 2 Diabetes Mellitusun Serbest Doku Nakli Başarısına Etkisi. Türk Diyab Obez 2020;1: 1-6.
}

\begin{abstract}
ÖZET
Amaç: Geniş doku defektlerinde serbest doku nakli hâlâ altın standarttır. Başarısı damar anastomozuna bağlı olan serbest doku nakli, damarı etkileyen her durumdan etkilenecektir. Bunların başında da Tip 2 Diabetes Mellitus gelmektedir. Bununla birlikte serbest doku nakli işlemlerinde diyabetin başarıya etkisi hâlâ yeteri kadar incelenmemiştir. Bu nedenle, bu çalışmada serbest doku nakli yapılan, diyabetik ve non-diyabetik hasta gruplarını, komplikasyon ve başarı oranları açısından karşılaştırmayı amaçladık.

Gereç ve Yöntemler: Atatürk Üniversitesi, Tip Fakültesi, Plastik, Rekonstrüktif ve Estetik Cerrahi Kliniği’nde Ocak 2010 - Ocak 2019 arasında, serbest doku nakli yapılan, 40 yaş üstü 107 hasta çalışmaya dahil edildi. Tip 2 Diabetes Mellitus tanısı olan 18 (Grup 1) ve diyabeti olmayan 89 (Grup 2) olgu, komplikasyon oranları ve ameliyat başarısı açısından karşılaştırıldı.

Bulgular: Grup 1'de \%22,2, Grup 2'de \%5,6 oranında arteriyel trombüs gelişti ( $\mathrm{p}=0,021)$. Grup 1'deki hastalara istatistiksel olarak anlaml derecede daha fazla revizyon ameliyatı gerekti $(\mathrm{p}=0,030)$. Grup 1'de $\% 33,3$, Grup 2'de ise $\% 13,5$ oranında nakledilen doku başarısızlıkla sonuçlandı $(\mathrm{p}=0,040)$. İstatistiksel olarak anlamlı bulunmasa da Grup l'deki hasta grubunda daha sık intra-postoperatif anastomoz problemi ve hematom komplikasyonu görüldü.

Sonuç: Serbest doku nakli yapılacak diyabetik hastalarda, daha fazla komplikasyon görülür ve başarı oranı daha düşüktür. Bu nedenle ameliyat öncesi ayrıntılı değerlendirme ve ameliyat sonrası sıkı takip gerektirmektedir.
\end{abstract}

Anahtar Sözcükler: Diabetes mellitus, Serbest doku nakli, Serbest flep

\section{The Effects of Type 2 Diabetes Mellitus on the Success of Free Tissue Transfer}

\begin{abstract}
Aim: Free tissue transfer is still gold standard in wide tissue defect treatments. Free tissue transfers whose success depends on vascular anastomosis will be affected by every situation which affects vessels. Diabetes mellitus is a worldwide well known vasculopatic disorder . Although, it has serious deteriorative effects on all vascular anatomy and physiology, the effects of diabetes mellitus on the success of free tissue transfer surgery hasn't been well studied yet. In this study, we aimed to investigate the effects of diabetes mellitus on the success and complications of free tissue transfer surgery.

Material and Methods: 107 adult patients who undertook free tissue transfer surgery in Plastic, Reconstructive and Aesthetic Surgery Department of Atatürk University Medical Faculty between January 2010 and January 2019 were included in this study. Patients were divided into two groups as Group 1 (18 patients with Diabetes Mellitus) and Group 2 (89 patients without diabetes mellitus). The groups were compared for surgical complications and success.

Results: Arterial thrombosis was found as $22.2 \%$ in group 1 and $5.6 \%$ in Group $2(\mathrm{p}=0.021)$. Diabetic patients needed more revisional surgery than non-diabetic cases ( $\mathrm{p}=0.030$ ). Surgeries failed in $33.3 \%$ of cases in Group 1 and $13.5 \%$ of patients in Group $2(\mathrm{p}=0.040)$. The frequency of intra-postoperative anastomosis problems and heamatomas were higher in diabetics than non-diabetics, but the difference was not statistically significant.

Conclusion: In free tissue transfer surgery, we found more complications and low-success rate in diabetic cases than non-diabetics. Diabetic cases need more attention and close follow-up period after free tissue transfer surgery.
\end{abstract}

Key Words: Diabetes mellitus, Free tissue transfer, Free flap

ORCID: Hakan Çinal / 0000-0002-9797-5730, Ensar Zafer Barın / 0000-0002-0380-8553 


\section{GİRIS}

Serbest doku nakli (SDN), rekonstrüktif merdivenin son basamağı olarak, son 30 yılda yaygın bir uygulama haline gelmiştir. Tecrübeli ellerde ulaşılmış yüksek başarı oranları, transfer edilecek mevcut dokunun çok yönlülüğ̈̈ ve güvenli olması bu uygulamanın yaygın hâle gelmesini sağlamıştır (1). Doku defektini onarmak için nakledilen, kendi damar ağını içeren bir doku segmentine flep denir. Bu flebin defekt bölgesindeki uygun bir damara mikrocerrahi yöntemler kullanarak anastomoz edilmesi ile SDN yapılmış olur. SDN çok uygulanan bir işlem hâline gelmesine rağmen eşlik eden tıbbi durumların cerrahi sonuçlara etkisinin ne olduğu hâlâ yeterince incelenmemiştir $(2,3)$. Başarısı damar anastomozu başarısına bağlı olan SDN, damarı etkileyen her durumdan etkilenir (4). Bunların başında da Diabetes Mellitus (DM) gelir. DM’nin tüm vücuttaki damar ağına ciddi hasarından dolayı, bu hastalar rekonstrüksiyon cerrahları açısından problemli bir gruptur (5). Çalışmalar, kontrolsüz hipergliseminin ateroskleroza ve tromboz gelişimine yatkın olduğunu göstermektedir (6). Türkiye'de diyabet tanısı olan yaklaşık 6 milyon kişi vardır ve yılda \%6 oranındaki bir hızla artmaktadır (7). Bu da göstermektedir ki, tüm cerrahi müdahalelerin komplikasyon oranlarını artıran bu hastalığın önlenmesine ve etkilerinin araştırılmasına ihtiyaç gittikçe artmaktadır. Biz bu çalışmamızda SDN yaptığımız diyabetik hastalar ile, aynı demografik özelliklere sahip diyabetik olmayan hastaların, cerrahi komplikasyon ve cerrahi başarı oranlarını karşılaştırmayı amaçladık.

\section{GEREÇ ve YÖNTEMLER}

Bu çalışma için Atatürk Üniversitesi Tip Fakültesi Klinik Araştırmalar Etik Kurulu'ndan onay alındı (30.05.201904/42). Ocak 2010 - Ocak 2019 arasında, Atatürk
Üniversitesi, Tıp Fakültesi, Plastik, Rekonstrüktif ve Estetik Cerrahi Kliniği'nde SDN yapılan hastaların verileri Helsinki Deklerasyonu Prensipleri'ne uygun şekilde geriye dönük olarak incelendi. Çalışmaya SDN yapılan, 40 yaş üstü 107 olgu dahil edildi. Tip 2 DM olan 18 (Grup 1) ve diyabeti olmayan 89 (Grup 2) olgu, komplikasyon oranları ve cerrahi başarı açıssından karşılaştırıldı. Bütün ameliyatlar aynı cerrahi ekip tarafindan yapildı.

Çalışmanın istatistikleri SPSS 19.0 paket programında yapıldı. Nitel değişkenlere ait tanımlayıcı istatistikler frekans ve yüzde ile nicel değişkenler aritmetik ortalama, medyan değerleriyle verilmiştir. Gruplardaki nominal parametrelerin karşılaştırılmasında ki kare testi kullanıldı. Nominal parametreler arasındaki ilişkilerin değerlendirilmesi parsiyel korelasyon testi ile yapıldı. Çalışmadaki tüm istatistiksel analizlerde p değeri 0,05 'in altındaki sonuçlar istatistiksel olarak anlamlı kabul edildi.

\section{BULGULAR}

Diyabetik olan Grup 1'in yaş ortalaması 6006, diyabetik olmayan Grup 2'nin yaş ortalaması 54,49 yıl olarak bulundu. Grup 1'in \%50'si, Grup 2'nin \%58,4'ü erkek hasta idi. Yaş ve cins açısından her iki grup arasında anlamlı fark yoktu ( $>0,05)$ (Tablo 1). SDN için her hastaya tek arter anastomozu yapilırken, Grup 1'de ortalama 1.5, Grup 2'de 1.55 ven anastomozu yapıld 1 ( $\mathrm{p}=0,690)$. Grup 1'deki hastalara istatistiksel olarak anlamlı derecede daha fazla revizyon ameliyatı gerekti $(\mathrm{p}=0,030)$. Grup 1'de hipertansiyon $(\mathrm{HT})$ tanısı olan hasta oranı daha fazlaydı ( $\mathrm{p}=0,0001)$ (Tablo 1 ). Gruplar arasında sigara kullanımı, periferik damar hastalığı $(\mathrm{PDH})$, koroner arter hastalığı (KAH), kronik obstrüktif akciğer hastalı̆̆ $1(\mathrm{KOAH})$ açısından istatistiksel olarak anlamlı fark yoktu (Tablo 1).

Tablo 1: Olgulara ait demografik verilerin karşılaştırılması.

\begin{tabular}{|c|c|c|c|c|c|}
\hline & \multicolumn{2}{|c|}{ Diyabeti olan hasta (Grup 1) } & \multicolumn{2}{|c|}{ Diyabeti olmayan hasta (Grup 2) } & \multirow[t]{2}{*}{$\mathbf{P}$} \\
\hline & $\mathbf{n}$ & $\%$ & $\mathbf{n}$ & $\%$ & \\
\hline Yaş (y1l) & 60,06 & & 54,49 & & 0,070 \\
\hline Erkek & 9 & 50 & 52 & 58,4 & \multirow{2}{*}{0,510} \\
\hline Kadın & 9 & 50 & 37 & 41,6 & \\
\hline Ven anastomoz sayısı & 1,50 & & 1,55 & & 0,690 \\
\hline Revizyon sayısı & 0,39 & & 0,15 & & $\mathbf{0 , 0 3 0}$ \\
\hline Sigara $(+)$ & 1 & 5,6 & 7 & 7,9 & 0,734 \\
\hline $\mathrm{PDH}(+)$ & 1 & 5,6 & 4 & 4,5 & 0,846 \\
\hline $\mathrm{HT}(+)$ & 12 & 66,7 & 19 & 21,3 & 0,0001 \\
\hline $\mathrm{KAH}(+)$ & 5 & 5,6 & 3 & 16,7 & 0,104 \\
\hline $\mathrm{KOAH}(+)$ & 2 & 11,1 & 2 & 2,2 & 0,071 \\
\hline
\end{tabular}

PDH: Periferik damar hastalığı, HT: Hipertansiyon, KAH: Koroner arter hastalığı, KOAH: Kronik obstrüktif akciğer hastalığı. 
Gruplar arasinda intra-postoperatif anastomoz problemi, venöz trombüs, hematom oluşumu açısından fark yoktu (Tablo 2). Ancak Grup 1'de (\%22,2), Grup 2'den (\%5,6) daha sik arteriyel trombüs gelişti $(\mathrm{p}=0,021)$. Son olarak, Grup 1'de \%33,3, Grup 2'de ise \%13,5 oranında, nakledilen doku nekroza giderek başarısızlıkla sonuçlandı. Grup 1'de istatistiksel olarak anlamlı derecede daha az flep başarısı elde edildi $(\mathrm{p}=0,040)$ (Tablo 2$)$.

Grup 1 hastalarında anlamlı derecede daha fazla HT tanısı almış hasta bulunuyordu. Bu parametrenin etkisini ortadan kaldırıp sadece diyabetin etkisini değerlendirmek üzere parsiyel korelasyon analizini kullandık ve diyabet varlığ flep sağ kalım oranını anlamlı derecede olumsuz etkiledi $(\mathrm{r}=-0,206, \mathrm{p}=0,035)$.

\section{TARTIŞMA}

Serbest doku transferi rekonstrüktif cerrahide, doku defektlerinin tamirinde son basamaktır. Ancak bu metodun başarısı damarsal pedikülü etkileyen faktörlerden direkt olarak etkilenmek-tedir. $\mathrm{Bu}$ faktörler arasında DM önemli yer tutmaktadır $(2,3,8,9)$. DM oranı Türkiye'de yapılan epidemiyolojik çalışmalarda 40 yaş üzerinde $\% 15$ olarak bulunmuştur ve bu oran ile Avrupa birincisi durumundadır (10). Ülkemizde hem DM oranı artmaya devam etmekte $(7,10)$, hem de tıbbi bakım imkanlarının genişlemesi ile diyabetik hastalarda beklenen ömür uzamaktadır. Sonuç olarak, diyabetik hastalarda gerek diyabetin komplikasyonlarına bağlı olarak gerekse de diyabet dışı nedenlerle SDN ihtiyacı giderek artacaktır. Bununla birlikte diyabetin, SDN başarısı üzerindeki etkisi yeteri kadar araştırılmamıştır $(2,3)$.

Fareler üzerinde yapılan deneysel çalışmalar, diyabetik hastaların damar intimalarında onarım yeteneğinde bozulma olduğunu (11), endotelizasyon derecesinin kontrol gruplarıyla karşılaştırıldığında azaldığını ve bu nedenle mikrovasküler anastomoz başarısının daha düşük olduğunu göstermiştir (12).

Diyabete bağlı metabolik düzensizlik damar duvarının tüm hücresel yapılarını olumsuz etkileyerek ateroskleroza neden olur (13). Ateroskleroz flep yetmezliği ve postoperatif komlikasyonlar için bilinen bir risk faktörüdür. Aterosklerotik değiş̧iklikler damar elastikiyetini ve kompliyansını düşürür ki, bu da anastomozdaki kan akımını azaltarak flep yaşayabilirliğini azaltır (14).

Diyabette mikroskopik yapısal değişim kapiller bazal membran kalınlaşması (15) ve azalmış bölgesel kan akımıdır (16). Diyabet, SDN işleminin sonucunu etkileyebilecek mikroanjiyopati ve immün yetmezliğe ya da her ikisine de neden olur ve vücudun tüm vasküler yapısını ve organlarını etkiler (3). Dolayısıyla diyabetik hastalarda tromboz daha sık görülür (6). Randon ve ark. ekstremite tehdidi gösteren geniş yumuşak doku defektleri olan tip 2 diyabeti olan 55 hastaya kombine revaskülarizasyon ve serbest kas flep işlemi gerçekleştirdi ve bunların\% 62'sinde erken tromboz gördü. (17). Bozikov ve Arnez, SDN yapilan diyabetik hastalarda infeksiyon, hematom, arteriyel ve venöz tromboz gibi komplikasyonların 5 kat daha fazla görüldügünü gösterdiler (18).

Yine DM'un en bilinen komplikasyonlarından birisi de iyileşmeyen cilt ülserleridir ki bu yaralar sıklıkla cerrahi rekonstrüksiyon gerektirirler (5). Hastaneye yatırılan diyabetik hastaların yaklaşık \%20'si ayak ülseri şikayeti ile başvurmaktadır (5). Yine ekstremite kaybı ile sonuçlanan tüm amputasyonlar içinde diyabetik ayak ülseri \%84 oranı ile majör etiyolojik faktördür (19). Diyabetik hastalarda diyabetik ayak ülseri gelişiminde üç patolojik durum etkilidir; arteroskleroz, periferik nöropati ve mikroanjiopati (20). Bu patolojik durumlardan arteroskleroz ve mikroanjiopati dolaşımı bozarak, periferik nöropati ise yara oluşmasını kolaylaştırıcı patolojik şartlar oluşturarak diyabetik ayak ülseri gelişimine katkıda bulunur. Nekroz ve doku kaybı bir kez oluştuğunda olaya eklenen infeksiyon bir kısır döngü yaratarak nekroz ve doku kaybının daha da ilerlemesine neden olur (21). Netice de yaranın onarımı için SDN'den başka çare kalmaz (Şekil 1-6). Yine bu sebeplerle diyabetik hastalarda bu yaraların SDN ile rekonstrüksiyonu, non-diyabetik hastalara göre daha düşük başarı oranına sahiptir (22).

Tablo 2: Olgulara ait cerrahi verilerin karşılaştırılması.

\begin{tabular}{lccccc}
\hline & \multicolumn{2}{c}{ Diyabeti olan hasta (Grup 1) } & Diyabeti olmayan hasta (Grup 2) & P \\
\cline { 2 - 6 } & $\mathbf{n}$ & $\mathbf{\%}$ & $\mathbf{n}$ & $\mathbf{\%}$ & \\
\hline İntraoperatif anastomoz problemi & 1 & 5,6 & 1 & 1,1 & 0,205 \\
\hline Postoperatif perfüzyon problemi & 3 & 16,7 & 5 & 5,6 & 0,104 \\
\hline Venöz trombüs & 1 & 5,6 & 6 & 6,7 & 0,853 \\
\hline Arteriyel trombüs & 4 & 22,2 & 5 & 5,6 & $\mathbf{0 , 0 2 1}$ \\
\hline Hematom & 3 & 16,7 & 6 & 6,7 & 0,166 \\
\hline Flep să̆ kalım & 12 & 66,7 & 77 & 86,5 & $\mathbf{0 , 0 4 0}$ \\
\hline
\end{tabular}




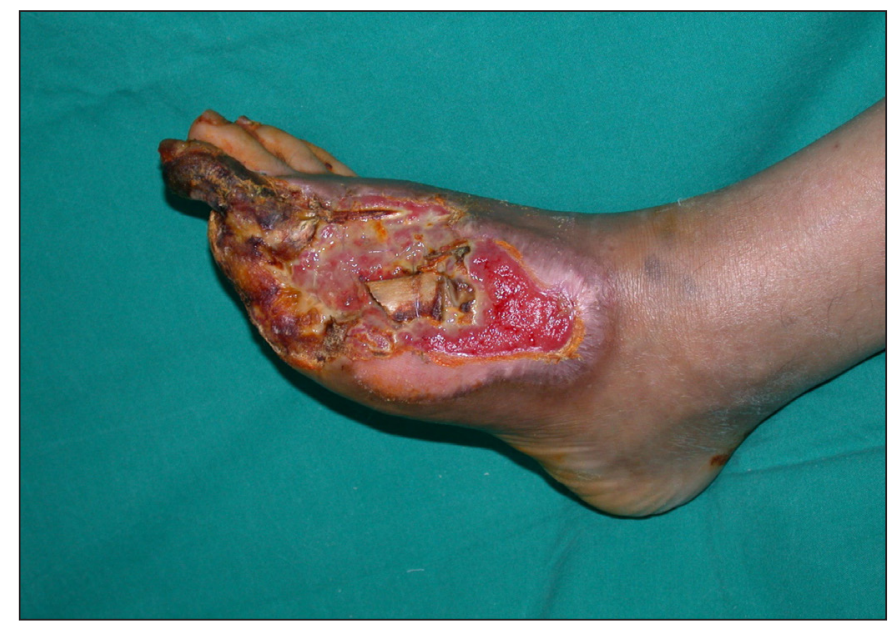

Şekil 1: Diyabetik ayak yarası.

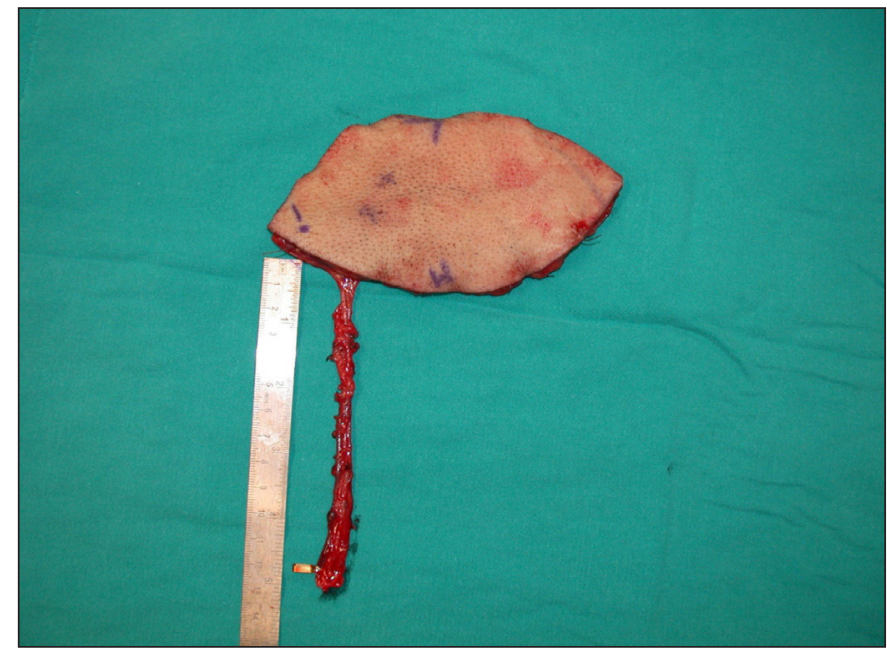

Şekil 3: Serbestleştirilmiş anterolateral uyluk flebi ve pedikülü.

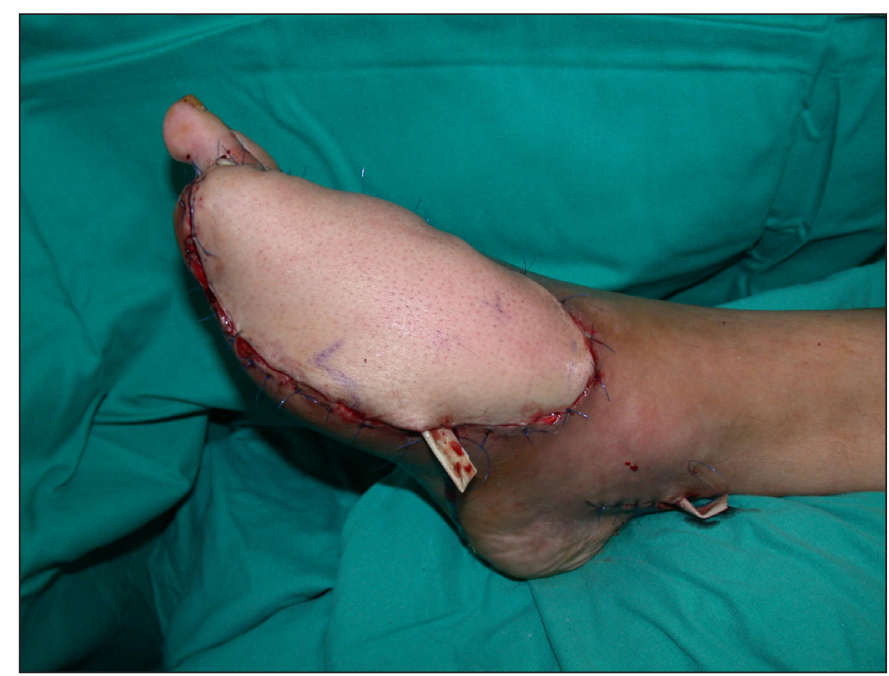

Şekil 5: Serbest doku nakli, ameliyat sonrası görünümü.

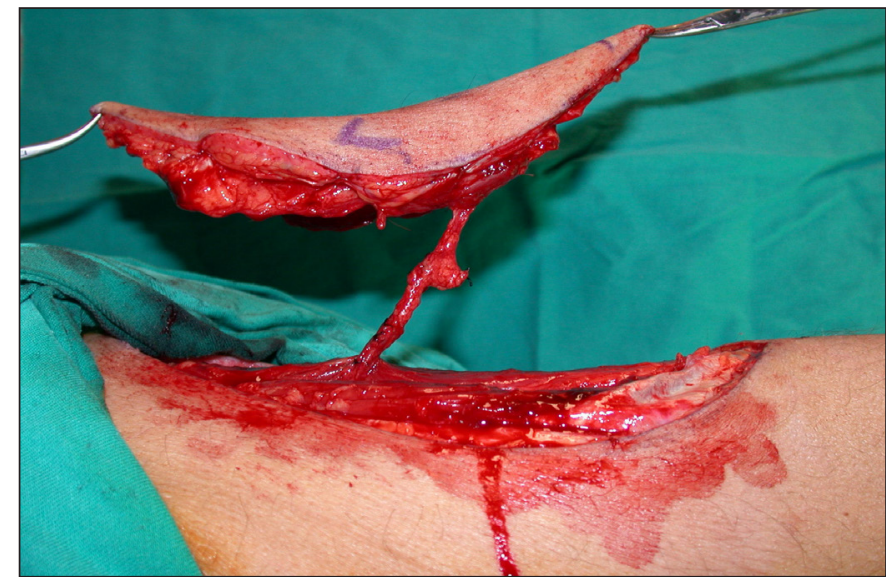

Şekil 2: Diyabetik ayak yarasını kapatmak için kaldırılan serbest anterolateral uyluk flebi.

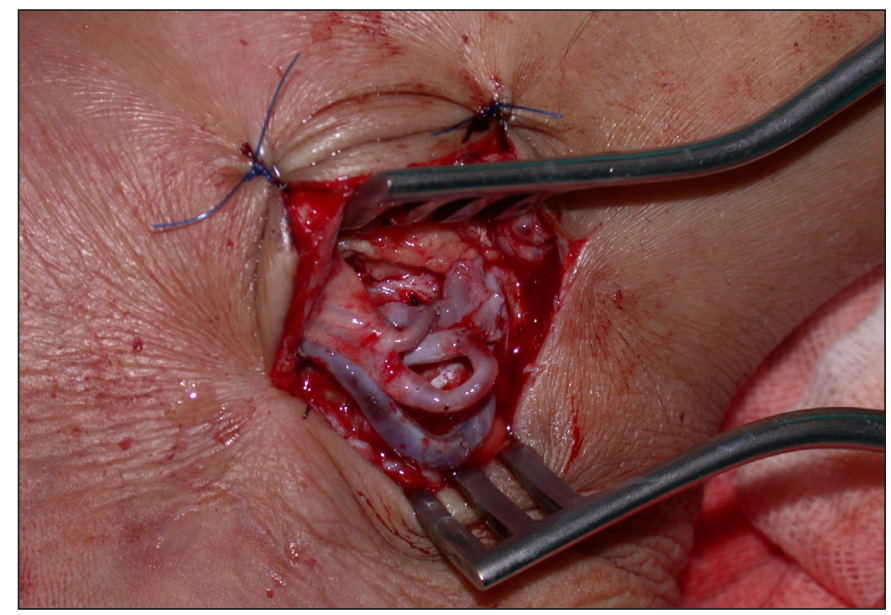

Şekil 4: Flep pedikülünün, posterior tibial arter ve vene uç-yan ve uç-uca anastomozu.

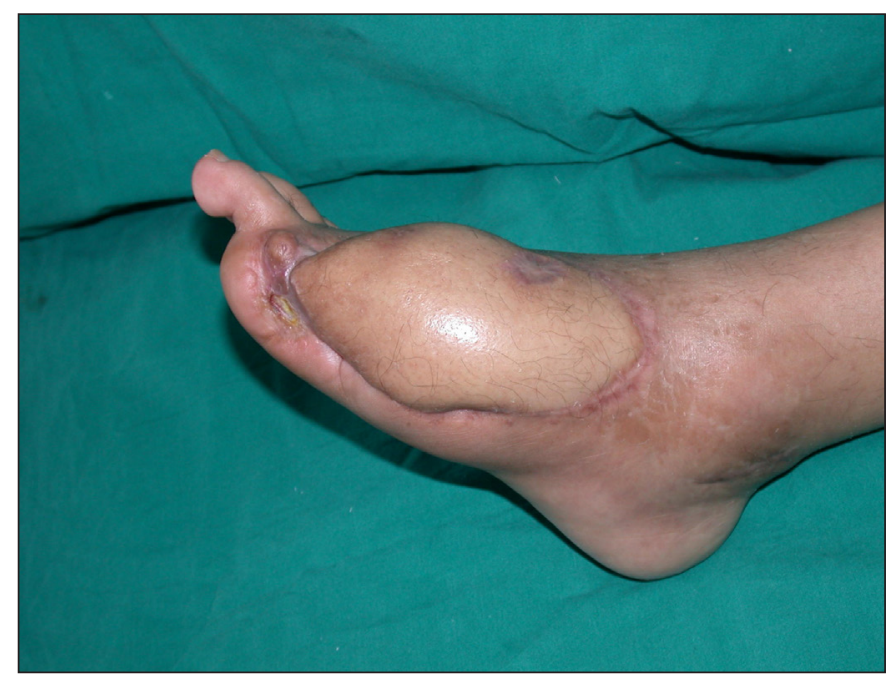

Şekil 6: Serbest doku nakli, 6 ay sonra görünümü. 
Deneyimli ellerde SDN'nde başarı oranları \%80'nin üzerine çıkmıştır (3). Oh ve ark.nın yaptığı çalışmada SDN yapılan 121 diyabetik olgunun 24'ünde (\%19.8) kısmi veya tam flep kaybı, 4 olguda venöz, bir olguda arteriyel yetmezlik ve 5 olguda ise baskın bir neden olmaksızın flepte dolaşımında bozulma tespit edilmiştir (5). Başka bir çalışmada, serbest flep yetmezliği olan hasta grubunda DM prevalansı, genel populasyondan 2.3 kat daha fazla bulunmuştur (2). Ducic ve ark. yaptığı çalışmada ise diyabetin varlı̆̆ı, yara başına ameliyat sayısının ve iyileșme süresinin iki katına çıkmasına neden olmuştur (8).

Bizim çalışmamızda ise diyabetik olguların olduğu Grup 1'de \%33.3, Grup 2'de ise \%13.5 oranında nakledilen doku nekroza giderek başarısızlıkla sonuçlandı. Grup 1'de istatistiksel olarak anlamlı derecede daha fazla flep kaybı yaşandı. Grup 1'de, Grup 2'den yaklaşık 4 kat daha sık arteriyel trombüs gelişti. Grup 1'deki hastalarda, flep dolaşım yetmezliği nedeni ile daha fazla revizyon ameliyatı gerekti. İstatistiksel olarak anlamlı bulunmasa da Grup 1'deki hasta grubunda daha sik intra-postoperatif anastomoz problemi ve hematom görüldü. Literatüre paralel olarak SDN yapılan olgularda daha sık komplikasyon ve daha az flep başarı oranları elde edildi.

Grup1'deki hastalarda HT tanısı olan olgu sayısı anlamlı derecede fazlaydı. Bu değişken aynı zamanda flep sağ kalımına da potansiyel negatif etkili olabilecek faktördür. $\mathrm{Bu}$ parametrenin etkisini ortadan kaldırıp sadece diyabetin etkisini değerlendirmek üzere parsiyel korelasyon analizini kullandık. Böylece HT ve ek hastalığın etkisini ortadan kaldırarak diyabetik flep üzerine etkisini tekrar değerlendirdik. $\mathrm{Bu}$ durumda dahi diyabet varlığ 1 flep sağkalım oranını anlamlı derecede olumsuz etkiledi.

$\mathrm{Bu}$ makalede sunduğumuz deneyim göstermiştir ki, SDN yapılacak diyabetik hastalarda daha yüksek komplikasyon olasılığı vardır ve ameliyat sonrası sıkı takip gerekliliğinin yanı sıra, özellikle aterosklerozlu hastalar için ameliyat öncesi değerlendirme dikkatli bir şekilde yapılmalıdır. Bazı yazarlara göre diyabetli hastalar, SDT için göreceli kontrendikasyon olarak kabul edilmesine rağmen yapılacak yeni çalışmalar sayesinde diyabetin negatif etkisinin daha iyi anlaşılıp, başarı oranlarının daha yukarılara taşınacağına inaniyoruz.

\section{Çılkar Çatışması}

Çalışmada herhangi bir çıkar çatışması yoktur.

\section{Finansal Destek}

Çalışmada herhangi bir finansal destek yoktur.

\section{Yazarların Makaleye Katkı Beyanı}

Fikir, analiz ve yorum, eleştirel inceleme, revizyon: Hakan Çinal, Tasarım, literatür taraması, veri toplama ve işleme, yazım: Hakan Çinal ve Ensar Zafer Barın.

\section{KAYNAKLAR}

1. Wong $\mathrm{CH}$, Wei FC. Microsurgical free flap in head and neck reconstruction. Head Neck. 2010;32:1236-1245.

2. Rosado P, Cheng HT, et al. Influence of diabetes mellitus on postoperative complications and failure in head and neck free flap reconstruction: A systematic review and meta-analysis. Head Neck. 2015;37(4):615-618.

3. Valentini V, Cassoni A, et al. Diabetes as main risk factor in head and neck reconstructive surgery with free flaps. J Craniofac Surg. 2008;19(4):1080-1084.

4. Alberdas JL, Shibahara T, et al. Histopathologic damage to vessels in head and neck microsurgery. J Oral Maxillofac Surg. 2003;61:191-196.

5. Oh TS, Lee HS, et al. Diabetic foot reconstruction using free flaps increases 5-year-survival rate. J Plast Reconstr Aesthet Surg. 2013;66(2):243-250.

6. Colen LB, Stevenson A, et al. Microvascular anastomotic thrombosis in experimental diabetes mellitus. Plast Reconstr Surg. 1997;99:156-162.

7. Onat A, Can G, et al. Özet ve sonuçlar. Onat A, Editör. TEKHARF 2017 Tip Dünyasının Kronik Hastalıklara Yaklaşımına Öncülük, İstanbul, Logos Yayıncılık, 2017, p.5.

8. Ducic I, Attinger CE. Foot and ankle reconstruction: Pedicled muscle flaps versus free flaps and the role of diabetes. Plast Reconstr Surg. 201;128(1):173-180.

9. Attinger CE, Ducic I, et al. The role of intrinsic muscle flaps of the foot for bone coverage in foot and ankle defects in diabetic and nondiabetic patients. Plast Reconstr Surg. 2002;110(4):1047-1057.

10. Satman I, Omer B, et al; TURDEP-II Study Group. TURDEPII Study Group. Twelve-year trends in the prevalence and risk factors of diabetes and prediabetes in Turkish adults. Eur J Epidemiol. 2013;28(2):169-180.

11. Barr LC, Joyce AD. Microvascular anastomoses in diabetes: An experimental study. Br J Plast Surg. 1989;42:50-53.

12. Cooley BC, Hanel DP, et al. The influence of diabetes on free flap transfer: I. Flap survival and microvascular healing. Ann Plast Surg. 1992;29(1):58-64.

13. Beckman JA, Creager MA, et al. Diabetes and atherosclerosis: Epidemiology, pathophysiology, and management. J Am Med Assoc. 2002;287(19):2570-2581.

14. McCullough PA, Agrawal V, et al. Accelerated atherosclerotic calcification and Monckeberg's sclerosis: A continuum of advanced vascular pathology in chronic kidney disease. Clin J Am Soc Nephrol. 2008;3(6):1585-1598. 
15. Aagenaes O, Moe H. Light-and electron-microscopic study of skin capillaries of diabetics. Diabetes. 1961;10: 253-259.

16. Katz MA, McCuskey $P$, et al. Relationships betvveen microvascular function and capillary structure in diabetic and nondiabetic human skin. Diabetes. 1989;38:1245-1250.

17. Randon C, Vermassen F, et al. Outcome of arterial reconstruction and free-flap coverage in diabetic foot ulcers: Long-term results. World J Surg. 2010;34(1):177-184.

18. Bozikov K, Arnez ZM. Factors predicting free flap complications in head and neck reconstruction. J Plast Reconstr Aesthet Surg. 2006;59:737-742.
19. Levin ME. Diabetic foot ulcers: Pathogenesis and management. JET Nurs. 1993; 20(5):191-198.

20. Hatz RA, Niedner R, et al. In: Diabetic leg ulcer, Woundhealing and wound management, Berlin, Springer-Vcrlag, 1994, p.98105.

21. Aygit AC, Top H, et al. Diyabetik ayak ülserinde yara bakımı ve cerrahi girişimler. Turk J Plast Surg. 2003;11(3):153-158.

22. Lee YK, Park KY, et al. Analysis of multiple risk factors affecting the result of free flap transfer for necrotising soft tissue defects of the lower extremities in patients with type 2 diabetes mellitus. J Plast Reconstr Aesthet Surg. 2014;67(5):624-628. 